\title{
THE IMPLEMENTATION OF COUNSELING COLLABORATIVE BASED LEARNING TO IMPROVE STUDENTS' CREATIVE THINKING ABILITY (A CASE STUDY ON SPECIAL NEEDS EDUCATION STUDENTS IN UNINUS)
}

\author{
Husen Saeful Insan \\ Universitas Islam Nusantara, Bandung
}

\begin{abstract}
There are many factors that influence the less successful learning activity in special needs education study program at UNINUS. Those factors among others lecturer still not maximize students' creative thinking abilities, lack of attention to students' capabilities and experiences, less attention to students' complaints related to learning, less in valuing students' opinions and less recognizing and strengthen students' positive actions. Therefore, it is necessary to develop learning model that can improve students' creative thinking ability. This study is trying to develop the learning model based on collaborative counseling that will be done in three years. The purpose of this first year study is to make draft of a model that has been tested its feasibility. To achieve the objectives, the researcher implement Research and Development design through these following stages:preliminary study, designing hypothetical model, testing the feasibility of hypothetical model, improving the hypothetical model,field testing of hypothetical model, and designing of the final model based on counseling collaborative learning. The subjects of this research were students and lecturers. The data was collected using questionnaire and interview and analyzed quantitatively and qualitatively. The results shows that most of the student are in the middle category. It also reveals that the process of learning has not optimally develop students creative thinking ability. Based on the result it was recommended for teachers and counselors to develop students' creative thinking, to build a harmonious relationship, and to build partnership and collaboration with students.
\end{abstract}

Keywords: counseling collaborative, creative thinking ability

\section{INTRODUCTION}

Lessons that was held in the college should be able to create conducive conditions to change innapropriate attitudes and habits of study. Students' high learning autonomy and creative thinking abilities will facilitate them in learning, otherwise students' low capacity lead the students encounter many obstacles. Learning activity in higher education needs to be arranged based on a plan agreed by students and faculty. Students serve as partners in learning, so that learning is not only controlled by faculty as a teacher but as a collaborative activity between lecturers and students. Cooperative relationships will lead to positive impact on students' creative thinking the ability.

Students' creative thinking ability is one of the goals that need to be achieved from learning when students complete the study. During the process of study, students should be able to read the course material independently, listening and summarize the material they read, make paper, summarizing books, reports, clipping, preparing for exams, doing the exams, and solve learning problems. Furthermore, during the work time people should be able to do their job by themselves, to develop skills, to practice many clues and to solve problems. 
The observations indicate that many lecturers in Special Needs education study program still not be able to implement an optimal learning in terms of: (1) increase students' creative thinking ability (2) adjust material to the learning needs and problems faced by students; (3) utilize learning devices (4) foster harmonious relationship with the students; and (5) describe undertaken learning strategies; (6) make an agreement on the activities to be performed (7) maximize students' ability, students' excellence and students' experiences related to learning materials; (8) inisiate some changing in thinking and acting regarding to learning; (9) give assignment to increase students' responsibility; (10) encourage students to read more; and (10) sensitize students on their strength and weakness.

Based on description above, it can be concluded that most of the lecturers have not been able to perform learning based on the relationship, cooperation, participation, and maximizing students' potential. Therefore learning that can improve creative thinking ability must be done optimally. In order students have the ability to think creatively, they need to be prepared through a learning process that not only develop their cognitive abilities, but also carried out by the learning process based on the guidance that is able to develop creative thinking abilities aspects.

The learning model that seen as an appropriate to develop students' creative thinking skills is learning-based collaborative counseling. Learning-based collaborative counseling is learning process that constituted a support made by lecturers to the students that emphasize on partnership, cooperation, active participation. This learning model give students the opportunity to determine their difficulty in learning, their objectives and expected results, and has orientation on solving current and future problems as well as changes in learning skills and attitudes. (Hidayat, 2011:5).

\section{The concept of Collaborative Learning and Counseling}

Collaborative counseling is counseling that promotes collaborative partnerships and encourage students to participate actively. Hidayat (2012: 7) stated that counseling collaborative is a partnership committed by counselor and counselee that promotes partnerships, active participation, and the change in the counselee, gave directions and the opportunity to assert complaints, problems, objectives and results were prioritized, as well as optimize the capabilities, advantages, and their experience, with over, listening, respect, and validate the things they disclosed to enhance the learning skills of the counselee. To achieve these objectives, counselor must uncover and exploit the capabilities, advantages and experience of the counselee by listening what is told by counselee, listening to what is proposed, and appreciate and validate what counselee do.

Collaborative learning is learning-based counseling that is implemented based on a harmonious partnership, made a deal about learning, giving motivate, listen, appreciate, validate, uncover and exploit the capabilities, advantages, and experience of students to achieve the learning objectives. In implementing the collaborative learning, from the beginning lecturer must maintain regular contact with the students and explain everything thoroughly. Moreover, lecturer should ask questions to the students apropriately and thoroughly to all students. At the initial meeting of learning, teachers should make an agreement with the students about the use of models, approaches, strategies, methods, and techniques of learning. Lecturers should motivate the students to learn, listen to students' complaints and learning problems and willing to help them. 
Cropley in Munandar (1985: 9) argues that "creative thinking skills are skills creating ideas, about the possibility of an alternative, look at a combination of unexpected, and have the courage to try something unusual. The purpose of creative skills is to create new ideas that can be used to solve the problem. Moreover, Munandar (1985: 47) says that creative thinking is thinking to find many possible solutions to a problem with an emphasis on efficiency and diversity of answers". Further stated that the process of creative thinking can be seen through fluency, flexibility, originality of detail. If these areas can be seen in the process of one's thinking, then that person will be able to put forward the idea of a problem, be progressive, able to solve problems in various fields of life. There is visible gap between the demand to develop creativity of the counselee with the reality that exists in society. Therefore, counselee's creativity is needed to be developed through formal and informal education (Munandar, 1985).

Individual creativity will be determined by cognitive and personality. Cognitive aspects that influence creativity are intelligence and enrichment of thinking that shaped the experience and skills, while aspects of person personality that influence is the impulse of curiosity, selfesteem and self-confidence, self-contained nature, assertive nature, and courage to take risks. Creative thinking can be developed with exercises that are cognitive, especially thinking exercises, and practice non-cognitive like the attitude of daring to try something new, additional motivation to be creative, daring nature to risk, and the development of confidence and self-esteem (Davis \& Bull, 1978; Lott, 1978; Sobel, 1980; Munandar, 1985, in Nurhayati, 2010: 62). Based on the above opinion, the creative thinking indicator is access to informing, utilizing the resources, selecting information, organizing information, using information, developing their own information obtained, bringing new ideas, creating alternative solutions to problems, making decisions, exploring new ideas, criticizing and testing for yourself.

\section{Research procedure}

The research strategy used in this study is a research and development strategy proposed by Borg and Gall (1989: 781-782). They suggest 10 steps to be taken in conducting the research as simplified by Sukmadinata (2005: 189), namely: (1) a preliminary study, examines the theory and observing existing products or programs; (2) to develop a new product or program activities, (3) to test or validate the product or program and activities. While the analysis of the data used in this research is the analysis of qualitative and quantitative.

The stages of research to be conducted in this study consists of five phases of activity, namely: (1) preparation, (2) design a hypothetical model, (3) test the feasibility of hypothetical model, (4) improving the hypothetical model, (6) field test hypothetical model, (5) designing the final model. An instrument in this study is was the instrument that can measure students' creative thinking abilities. Aspects of students' creative thinking ability among others willingness to learn, positive thinking, and attitude and behavior change.

\section{Findings}

The data reaveals some findings concerning students' creative thinking ability, the implementation of collaborative counseling based learning, and students problems' and strength.

a) Student Creative Thinking Ability Profile. The profile of students' creative thinking ability were covers some aspects, among others (1) Accessing information, (2) Utilizing the sources 
of information, (3) Selecting the information, (4) Organizing information, (5) Developing information maximally, and (6) develop new idea.

The indicator of accessing information consists of: (1) retrieve information from the library, (2) taking information from newspapers, (2) retrieve information from the internet. The results shows in Table 1.

Tabel 1

Information Access

\begin{tabular}{llccc}
\hline N0 & \multicolumn{1}{c}{ Statements } & \multicolumn{3}{c}{ Percentage (\%) } \\
& \multicolumn{1}{c}{ Low } & Middle & High \\
\hline $1 \quad \begin{array}{l}\text { I took many information from a library to do } \\
\text { my assignments }\end{array}$ & 42 & 43 & 15 \\
$\quad \begin{array}{l}\text { I took many information from a newspaper to } \\
\text { do my assignments }\end{array}$ & 40 & 46 & 14 \\
$\quad \begin{array}{l}\text { I took many information from internet to do } \\
\text { my assignments }\end{array}$ & 30 & 59 & 11 \\
$\quad$ Total & 112 & 138 & 40 \\
$\quad$ Average & 37,3 & 49,3 & 13,3 \\
\hline
\end{tabular}

The above table shows that the aspect of of students in accessing information from the library, $15 \%$ were in the high category, $43 \%$, in the category of medium and $42 \%$ are in the low category. On the indicator takes information from newspapers, $14 \%$ are in the high category, $46 \%$ in middle category, and $40 \%$ are in low category. On indicators about retrieve information from the internet, $11 \%$ are in the high category, $59 \%$ in middle category, and $30 \%$ are in low category.

In term of profile of students in utilizing information the high average of $13.3 \%$, while the middle of $45 \%$ and an average low of $40 \%$ which includes indicators using the resources of the library, using the resources of newspapers, use of internet resources that is shows in Table 2.

Table 2

Information Utilize

\begin{tabular}{lllcc}
\hline \multirow{2}{*}{ No } & \multicolumn{1}{c}{ Statements } & \multicolumn{3}{c}{ Percentage (\%) } \\
& & Low & Middle & High \\
\hline $1 \quad \begin{array}{l}\text { I often use information from library to enrich } \\
\text { my lecturing material }\end{array}$ & 50 & 32 & 18 \\
$\quad \begin{array}{l}\text { I often use information from newspaper to } \\
\text { enrich my lecturing material }\end{array}$ & 50 & 38 & 12
\end{tabular}




\begin{tabular}{llccc}
\hline \multirow{2}{*}{ No } & \multicolumn{1}{c}{ Statements } & \multicolumn{3}{c}{ Percentage (\%) } \\
& & Low & Middle & High \\
\hline \multirow{2}{*}{$3 \quad \begin{array}{l}\text { I often use information from internet to enrich } \\
\text { my lecturing material }\end{array}$} & 20 & 65 & 10 \\
\hline \multirow{2}{*}{ Total } & 120 & 135 & 40 \\
Average & 40 & 45 & 13,3 \\
\hline
\end{tabular}

Table 2 shows that the aspect students in accessing information in term of using the resources of the library, $12 \%$ are in the high category, $38 \%$, in the category of middle and $50 \%$ are in the low category. On indicators using resources from newspapers, $12 \%$ are in the high category, $38 \%$ are in middle category, and $50 \%$ are at a low category. On indicators using resources from the internet, $10 \%$ were in the high category, $65 \%$ in middle category, and $20 \%$ are at a low category.

Students profile in utilizing information sources, the high are at $15.3 \%$, while the middle are at $37 \%$ and the low at $51 \%$. It includes an indicator to select information from the library, select the information of the newspaper, selecting information from internet which is can be seen from Table 3.

Table 3

Information Selection

\begin{tabular}{llccc}
\hline \multirow{2}{*}{ No } & \multicolumn{1}{c}{ Statements } & \multicolumn{3}{c}{ Percentage (\%) } \\
& \multicolumn{1}{c}{ Low } & Middle & High \\
\hline $1 \quad \begin{array}{l}\text { I often select the information from library to } \\
\text { deepen lecturing material }\end{array}$ & 50 & 33 & 17 \\
$\quad \begin{array}{l}\text { I often select the information from newspaper } \\
\text { to deepen lecturing material }\end{array}$ & 51 & 33 & 16 \\
$\quad \begin{array}{l}\text { I often select the information from internet to } \\
\text { deepen lecturing material }\end{array}$ & 52 & 45 & 13 \\
& $\quad$ Total & 153 & 111 & 46 \\
$\quad$ Average & 51 & 37 & 15,3 \\
\hline
\end{tabular}

Table 3 shows that in term of selecting information information from the library, $17 \%$ were in the high category, $33 \%$, in the category of medium and $50 \%$ are in the low category. On the indicator of selecting information from newspapers, $16 \%$ were in the high category, $33 \%$ in middle category, and $51 \%$ are in the low category. On the indicator selecting information from the Internet, $13 \%$ were in the high category, $45 \%$ in middle category, and $52 \%$ are in the low category. 
The students' profile in utilizing information sources the high average are at $15.2 \%$, while the middle are at $49 \%$ and the low average are at $36 \%$ that includes indicators to collate the information submitted by the lecturers, sorting information from the internet relating to course materials, sorting library information related to the course material, linking information from the internet with the material subjects. The information could be seen in Table 4

Table 4

Information Organization

\begin{tabular}{|c|c|c|c|c|}
\hline \multirow{2}{*}{ No } & \multirow{2}{*}{ Statements } & \multicolumn{3}{|c|}{ Percentage (\%) } \\
\hline & & Low & Middle & High \\
\hline 1 & $\begin{array}{l}\text { I often organize information given by my } \\
\text { lecturing }\end{array}$ & 20 & 70 & 10 \\
\hline 2 & $\begin{array}{l}\text { I organize information from the internet that } \\
\text { connected with my lecturing subject }\end{array}$ & 29 & 54 & 17 \\
\hline 3 & $\begin{array}{l}\text { I organize information from the library that } \\
\text { connected with my lecturing subject }\end{array}$ & 48 & 37 & 15 \\
\hline 4 & $\begin{array}{l}\text { I often connected information from the } \\
\text { internet that connected with my lecturing } \\
\text { subject }\end{array}$ & 43 & 45 & 12 \\
\hline 5 & $\begin{array}{l}\text { I often connected information from the } \\
\text { library that connected with my lecturing } \\
\text { subject }\end{array}$ & 40 & 38 & 22 \\
\hline & Total & 180 & 245 & 76 \\
\hline & Average & 36 & 49 & 15,2 \\
\hline
\end{tabular}

Table 4 shows that aspects of the information organization in term of collating information from the lecturers, $10 \%$ are in the high category, $70 \%$ are in the middle category and $20 \%$ are in the low category. At the sorting indicator information from the Internet, $17 \%$ are in high category, $54 \%$ are in middle category, and $29 \%$ are in low category. At the indicator of sorting information from libraries, $15 \%$ arein high category, $37 \%$ in middle category, and $48 \%$ are in low category. On indicator about linking information from the Internet, $12 \%$ are in high category, $45 \%$ in middle category, and $43 \%$ in low category. On indicators on connected information from libraries, $22 \%$ are in the high category, $38 \%$ are in middle category, and $40 \%$ are in low category.

On students profile about information development, the high is at $16.75 \%$, while middle is $46 \%$ and the low is $32.25 \%$. It includes indicators about doing lecturing assignment by seeing examples, complete the task by using information from internet, library, and newspaper which can be seen in Table 5. 
Table 5

Maximum Information Development

\begin{tabular}{lllll}
\hline \multirow{2}{*}{ No } & \multicolumn{1}{c}{ Statements } & \multicolumn{3}{c}{ Percentage (\%) } \\
& \multicolumn{1}{c}{ Low } & Middle & High \\
\hline $1 \quad \begin{array}{l}\text { I often do my assignment by looking at the } \\
\text { example }\end{array}$ & 10 & 80 & 10 \\
$2 \quad \begin{array}{l}\text { I often do my assignment by by using } \\
\text { information from the internet }\end{array}$ & 29 & 53 & 18 \\
$3 \quad \begin{array}{l}\text { I often do my assignment by by using } \\
\text { information from the library }\end{array}$ & 48 & 30 & 22 \\
$\begin{array}{l}\text { I often do my assignment by by using } \\
\text { information from the newspaper }\end{array}$ & 42 & 31 & 17 \\
\hline & $\begin{array}{l}\text { Jumlah } \\
\text { Rata-rata }\end{array}$ & 32,25 & 46 & 16,75 \\
\hline
\end{tabular}

Table 5 shows that the aspect of doing the asssignment by looking at the example, $10 \%$ are in high category, $80 \%$ in the middle category and $10 \%$ are in low category. Completing tasks using information from the Internet, $18 \%$ are in high category, $53 \%$, in middle category and $29 \%$ are in low category. In term of doing assignment by using the information from the library, $22 \%$ are in high category, $30 \%$ are the middle category of and $48 \%$ are in low category.In term of completing tasks using information from newspapers, $17 \%$ are in high category, $31 \%$ are in middle category and $42 \%$ are in low category.

In term of students' profiles about bringing new genuine ideas on information development, $15.7 \%$ are high, $50 \%$ are middle and $34.3 \%$ are low. The information development covers answering questions using their own words, express a different opinion from other students, finding the main idea to solve the problem of learning, which is shows in Table 6.

Table 6

Genuine Information Development

\begin{tabular}{lllll}
\hline \multirow{2}{*}{ No } & \multicolumn{1}{c}{ Statements } & \multicolumn{3}{c}{ Percentage (\%) } \\
& Low & Middle & High \\
\hline 1 & $\begin{array}{l}\text { I often answer lecturer's question using my } \\
\text { own words }\end{array}$ & 22 & 64 & 14 \\
2 & $\begin{array}{l}\text { I often propose different opinion compre to } \\
\text { others }\end{array}$ & 52 & 35 & 13
\end{tabular}




\begin{tabular}{lllll}
\hline \multirow{2}{*}{ No } & \multicolumn{1}{c}{ Statements } & \multicolumn{3}{c}{ Percentage (\%) } \\
& & Low & Middle & High \\
\hline 3 & $\begin{array}{l}\text { I often find main idea to solve learning } \\
\text { problems }\end{array}$ & 29 & 51 & 20 \\
& Total & 103 & 150 & 47 \\
& Average & 34,3 & 50 & 15,7 \\
\hline
\end{tabular}

Table 6 shows that in term of aspects about answering questions from lecturer using their own words, $14 \%$ are at the high category, $64 \%$, in the category of medium and $22 \%$ are in the low category, expressed a different opinion from mahaisiswa more precisely, 52\% are in the high category, $35 \%$, in the category of medium and $13 \%$ are in the low category. finding the main idea to solve the problem studied, $29 \%$ were in the high category, $51 \%$, in the category of medium and $20 \%$ are in the low category.

\section{Student Creative Thinking Ability}

The findings show that on students profile concerning information most of the students are in the middle category, except in the term of accessing information which is in high category. The findings imply that the lecturer has role as inisiator for the students to think creative because the ability of creative thinking is needed to solve the problem so diverse in its current condition. In relation to the students' ability to utilize many resources, the use of information from the library is in the middle category, while the ability to access information from the internet is in the high category. It could understood because in the era of information and communication technology, the students prefer to access the resources on-line from the internet.

Students are prefer to find information from the internet because the information in the internet is more accessible and more interesting. However, sometimes internet make students do not creative. Therefore the lecturer are challanged to be able to give assignment that make the students still creative eventhough they use technology to asess the information within the internet.

To increase students' creative thinking ability, lecturers are expected to encourage students to be able to create new ideas this is because at the present time people need to think creatively. If they are not creative they would only become others's idea user. Munandar (1985: 47) argues that "creative thinking is thinking to find many possible solutions to a problem with an emphasis on efficiency and diversity of answers". Furthermore, he stated that that the process of creative thinking can be seen through fluency, flexibility, originality of detail. If the student has these four aspects, it will appear in they thinking process. Students will be able to convey right and diverse ideas with regard to problems that they faces. It could be seen in his daily life becaose they becomes more developed, and have the ability to solve problems related to college or student life.

Unfortunately, the creativity development informal education is still alarming (Semiawan, 1992; Munandar, 1985). There is gap between the demand to develop student creativity with 
the reality that exists in society. Therefore, the students' creativity still need to be developed, both through formal and informal education (Munandar, 1985). Students' creativity will be determined by cognitive and personality. The cognitive aspect is influenced by the ability to think and development of the concept in the form of experience and skills, while the personality aspects that influence is the impulse of curiosity, self-esteem and self-confidence, self-contained nature, assertive nature, and courage to take risks.

Based on the situation above students' creativity can be developed with collaborative counseling based learning, because it provides many learning exercises that are cognitive and non-cognitive. In the implementation of effective teaching learning, the teacher can use collaborative counseling, but firstly should understand the characteristics of true collaboration, and allowing parties to collaborate participate optimally. Cook and Frend (Frans \& Bursuck, 1996: 76) emerged out that the characteristics of collaboration are based on the voluntary, equality of relationships, shared goals, responsibility for results, willing to be a source, beliefs and counselee's interests. While the prerequisite for collaboration, are the existence of mutual trust, interaction skills and environment contribution (Hidayat, 2010).

Counseling Collaborative is a pattern that prioritizes the services of counselor so in full respect performance. It create something creatively, not looking problem from one perspective. Moreover it is not forcing to match counselee on one theory that dominated counselor, but the highest priority to the fact that happened on the counselee. The idea can be generated through conversation and interaction between counselor and counselee (Berger \& Luckmann in Bertolino and O, Hanlon, 2002: 4).

In a collaborative counseling, the counselor should be able to build a harmonious relationship with the counselee, determining complaints, prioritized problems and objectives, changing counselee's perspectives, behaviour and atmosphere, as well as being able to evaluate and determine future plans. Based on the study above, the meaning of counseling collaborative is the efforts provided by counselors to counselee that give priority so that counselor can build a collaborative relationship with the counselee, being in partnership with the counselee. Furthermore it should be able to provide opportunities and encourage counselees to participate, requires the counselor to many approached, listening, respect and validate performance, strength, and experience counselee, as well as full respect for the counselee.

Collaborative counseling Based learning is learning that emphasis on the lecturers and students relationship collaboratively. It build efforts to make partnership with the student in achieving the learning activities. Moreover it build efforts to make agreement on the planning, implementation and evaluation of learning. It also make an attempt to motivate the students, the effort to listen to, to appreciate, validate , uncover and exploit the capabilities, advantages, and experience of students to achieve the learning objectives.

Based on the results of the assessment on collaborative counselling based learning above, then in its implementation start from planning, implementing, and evaluating lecturers should foster and maintain a harmonious relationship with the students, then attempting not to place bad relations that will affect the teaching and learning activities.

Attention should be given to all students. As well as the views and questions, lecturers should give it proportionally and thoroughly to all students. If it is possible in the implementation of learning lecturer should do motoric improvisation. Teaching and learning activities conditions should be maintain from the beginning to always keep always conducive 
condition. In term of evaluation if it turns out that some students' results are not good lecturers should provide encouragement and opportunity to increase it.

In implementing collaborative counseling based learning there are some things that need to be considered by the lecturers, among others: (1) at the beginning of the meeting teachers should make an agreement with the students about the use of models, approaches, strategies, methods, and techniques of learning; (2) lecturers should provide motivation to the students for learning activities both in the classroom and outside the classroom; (3) lecturers should listen to students complaints and problems as well as trying to help; (4) lecturers should respect and validate the views, actions, and the atmosphere and the feeling of the student; (5) lecturer should be able to uncover and exploit students' capabilities, advantages, and experiences related to the course material that is being taught; (6) lecturer should consider students' ability, excellence, and experience when giving assignments and course material to keep students' learning spirit (7) all activities performed by the lecturers at the time of implementing the learning must be a goal-oriented on collaborative counseling based learning; (8) does not need to respond to students with pathological, instead should remove the excess of it so that students always have learning spirit.

\section{CONCLUSION}

Based on the the findings it can be concluded that: 1) Profile of students on the aspects: utilize the resources of the library, selecting information, organizing information, the development of the information manually, developing new ideas, creating alternative solutions to problems, make decisions appropriately and responsibly, explore and connect with others, and open to criticism mostly in the middle category.2) the implementation process has not yet develop students' creative thinking ability optimally, because it needs to be pursued by innovative learning model that gives students the opportunity to discover new ideas, develop new ideas and flexibility to solve problem. 3) problems faced by students including utilizing the resources from the library, selectin, organizing and developing information manually, which can bring new ideas, and create alternate problem-solving. Those skills must be pursued to increase, therefore the role of the faculty in implementing collaroborative counseling based learning to develop the ability to think creatively is very important. 4) Model-based learning collaborative counseling is innovative learning model that emphasizes harmonious relationship. Students considered as partners, aimed at the onset of changes in students' behavior, and emphasize the students to actively participate.

To improve students' creative thinking ability hopefully lecturers or counselor be able to perform following activities: 1) arrange condition to allow students to develop creative thinking abilities through learning activities.2) establish harmonious relationship, partnership and collaboration with students, especially when in teaching learning activity. 3) study collaborative counseling learning based model to improve the ability to think creatively and then implement and evaluate it. 4) Assess and validate hypothetical model then provide input to improve the model, and 5) Assess the impact after hypothetical model implemented. 


\section{REFERENCES}

Borg, W.R. \& Gall, M.D. (1989). Educational Research: An Introduction. New York: Longman.

Daradjat. (2001). Manajemen Prestasi Kerja. Jakarta. Rajawali Press.

Gall, M.D., et al. (2003). Educational Research: An Introduction. Boston: Pearson Education, Inc.

Nurihsan, Achmad Juntika. (2003). Dasar-Dasar Bimbingan dan Konseling. Bandung. Mutiara

(2006). Bimbingan dan Konseling Dalam Berbagai Latar kehidupan. Bandung. PT Refika Aditama

Prayitno. (1997). Pelayanan Bimbingan dan Konseling Prodi PLB FKIP Uninus Bandung Menengah Umum (SMU). Jakarta. Kerjasama Koprasi Karyawan Pusgrafin dengan Panebar Aksara.

Sukardi, Dewa Ketut. ( 2003). Manajemen Bimbingan dan Konseling di Sekolah. Bandung. Alfabeta.

Sukmadinata, Nana Syaodih. ( 2005). Metode Penelitian Pendidikan. Bandung: Program Pascasarjana Universitas Pendidikan Indonesia Kerjasama dengan PT Remaja RosdaKarya.

Undang-Undang Republik Indonesia No. 20 tahun 2003. Sistem Pendidikan Nasional. Jakarta. Depdiknas.

Winkel, W.S. (1991). Bimbingan dan Konseling di Institusi Pendidikan. Jakarta. PT Grasindo. 
64 Insan, The Implementation Of Counseling Collaborative Based Learning To ... 